\title{
Effects of using inquiry-based learning on EFL students' critical thinking skills
}

\author{
Bantalem Derseh Wale ${ }^{1 *}$ and Kassie Shifere Bishaw ${ }^{2}$
}

\author{
* Correspondence: bantalemd@ \\ gmail.com \\ ${ }^{1}$ Department of English Language \\ and Literature, Faculty of Social \\ Sciences and Humanities, Woldia \\ University, Woldia, Ethiopia \\ Full list of author information is \\ available at the end of the article
}

\begin{abstract}
The aim of this study was to examine the effects of using inquiry-based learning on students' critical thinking skills. A quasi-experimental design which employed time series design with single group participants was used. A total of $20 \mathrm{EFL}$ undergraduate students who took advanced writing skills course were selected using comprehensive sampling method. Tests, focus group discussion, and student-reflective journal were used to gather data on the students' critical thinking skills. The participants were given a series of three argumentative essay writing pretests both before and after the intervention, inquiry-based argumentative essay writing instruction. While the quantitative data were analyzed using One-Way Repeated Measures ANOVA, the qualitative data were analyzed through narration. The findings of the study revealed that using inquiry-based argumentative writing instruction enhances students' critical thinking skills. Therefore, inquiry-based instruction is suggested as a means to improve students' critical thinking skills because the method enhances students' interpretation, analysis, evaluation, inference, explanation, and self-regulation skills which are the core critical thinking skills.
\end{abstract}

Keywords: Inquiry-based learning, Critical thinking skills, Argumentative essay, Writing instruction, Time series design, English as a foreign language

\section{Introduction}

Critical thinking is the ability to ask and/or answer insightful questions in a most productive way in order to reach on a comprehensive understanding (Hilsdon, 2010). It consists interpretation, analysis, evaluation, synthesize explanation, inference, and self-regulation. Empowering critical thinking skills among students in higher education especially in academic writing through the integration of critical thinking into the teaching learning process is essential in order to develop students' problem solving, decision making and communication skills (Abdullah, 2014; Adege, 2016; McLean, 2005). Inquiry-based learning develops students' critical thinking skills because it helps students to develop interpreting, analyzing, evaluating, inferring, explaining, and self-regulation skills which are the core critical thinking skills (Facione, 2011; Facione \& Facione, 1994; Hilsdon, 2010).

The level of thinking depends on the level of questioning as long as the questioning leads to new perspectives (Buranapatana, 2006). When students learn to ask their own thought-provoking questions in and outside the classroom, and provide explanatory answers, they are well on the way to self-regulation of their learning. In inquiry-based

(c) The Author(s). 2020 Open Access This article is licensed under a Creative Commons Attribution 4.0 International License, which permits use, sharing, adaptation, distribution and reproduction in any medium or format, as long as you give appropriate credit to the original author(s) and the source, provide a link to the Creative Commons licence, and indicate if changes were made. The images or other third party material in this article are included in the article's Creative Commons licence, unless indicated otherwise in a credit line to the material. If material is not included in the article's Creative Commons licence and your intended use is not permitted by statutory regulation or exceeds the permitted use, you will need to obtain permission directly from the copyright holder. To view a copy of this licence, visit http://creativecommons.org/licenses/by/4.0/. 
writing instruction, students engaged in writing lessons and tasks that enhance their ability to apply these critical thinking skills because the method emphasize to produce texts through inquisition and investigation. In writing, when students' written papers realize these skills, the students considered that their critical thinking skills are developed.

Inquiry-based learning is the act of gaining knowledge and skills through asking for information (Lee, 2014). It is a discovery method of learning that involves students in making observations; posing questions; examining sources; gathering, analyzing, interpreting, and synthesizing data; proposing answers, explanations and predictions; communicating findings through discussion and reflection; applying findings to the real situation, and following up new questions that may arise in the process. Inquiry-based learning emphasizes students' abilities to critically view, question, and explore various perspectives and concepts of the real world. It takes place when the teacher facilitates and scaffolds learning than gives facts and knowledge so that students engage in investigating, questioning, and explaining their world in a student-centered learning environment.

Although inquiry-based learning is intended for science as it is classified as scientific approach, it can be implemented in language field. Rejeki (2017) mentioned that inquiry-based language learning is useful in promoting lifelong education that enables EFL learners to continue the quest for knowledge throughout life. Similarly, Lee (2014) stated that inquiry-based learning is an analogy for communicative approach. The principles of inquiry-based learning are compatible with Communicative Language Teaching because communicative approach focuses on communicative proficiency rather than mere mastery of structure to develop learners' communicative competence as to inquiry-based learning. Inquiry-based learning is, therefore, a form of Communicative Language Teaching which serves to bring down the general principles of communicative approach, and implement in language classrooms in an inquisitive and discovery manner (Lee, 2014; Qing \& Jin, 2007; Richards \& Rodgers, 2001). While communicative approach is an umbrella of various active language learning methods, inquiry-based learning is one of the active learning methods that drive learning through inquisition and investigation. It mainly focuses on discovery and learner cognitive development to be achieved using thoughtful questions.

In inquiry-based writing instruction, students engaged in pre-writing tasks through generating ideas, narrowing and clarifying topics; exploring information on their writing topics from various sources; explaining their discoveries gained from the exploration, and elaborating their thinking through transforming their understanding into the real world situation. When students come up through this distinct process in manipulating such tasks, their critical thinking skills can be enhanced because this process develops students' ability to analyze, synthesis, and evaluate concepts.

This study also revealed that students' critical thinking skills has been enhanced through inquiry-based writing instruction because the method focuses on the process of knowledge discovery that involves students in seeking, collecting, analyzing, synthesizing, and evaluating information; creating ideas, and solving problems through communication, collaboration, deep thinking, and learner autonomy. The study can contribute to the field of foreign language learning by possibly leading English language teachers and learners into a more effective language learning method. The study has applicable significances to EFL teachers to understand the nature and application of inquiry-based learning. 


\section{Literature review}

\section{Developing students' critical thinking skills through inquiry-based writing instruction}

Inquiry-based learning develops students' critical thinking skills because the method improves the students' mental activities such as interpretation, analysis, evaluation, explanation, inference, and self-regulation. Previous studies have shown that students' critical thinking abilities are significantly higher when students are taught through inquiry-based learning comparing with traditional teaching methods. Having a free medium of student learning class where students will share good experiences through an inquiry process that is based on curiosity is a preferred learning method to the act of teaching that characterized with teaching by forced (Ahmad, Sitti, Abdul, Mohammad, \& Sanitah, 2014; Iakovos, 2011).

By using inquiry-based learning in writing lessons, students can develop critical thinking skills, and learn how to generate and organize ideas through investigation or/ and discussion to find out alternative ideas, and produce sound written papers. Accordingly, students who used inquiry-based learning techniques in their language learning are better achievers because they have an active role in choosing the writing topics, and on developing the outcomes of their own investigations. Inquiry-based learning has impacts in EFL classes to help students improve the target language, and develop other abilities needed to understand this constantly changing world. When students participate in real life situations, they can develop effective research skills, adapt and respond better to change, and they are also prepared to the development of critical thinking skills (Escalante, 2013; Ismail, 2006; Lessner \& Craig, 2010).

Similar studies conducted by Ash and Kluger-Bell (2012); Byker, Harden, Heafner, and Holzberg (2017); Ahmad et al. (2014) discovered that learners preferred and performed much better with confirmation level of inquiry compared to guided, structured and open inquiry because teachers provide every needed conditions and allow the student the freedom to learn independently in the confirmation level. In the same vein, Ghaemi and Mirsaeed (2017) investigated the impacts of inquiry-based learning approach on critical thinking skill of EFL students, and revealed that doing inquiry-based activities in EFL classroom increased the critical thinking ability of the students.

Finally, Naryanti (2017) who conducted an action research to explore the extent to which inquiry-based learning method can improve grade eight students' ability in writing a descriptive text find out that inquiry-based learning method is able to improve the students' descriptive writing skills. The students concerned actively in the learning process, especially in conveying their opinions, asking and responding questions, and enthusiasm in producing written texts.

In sum, the aforementioned studies indicated that using inquiry-based learning in ESL/EFL writing classroom improves students' critical thinking skills, and help them to become lifelong mind seekers. However, most of the aforementioned studies were conducted on pretest-posttest two groups design unlike the present study which followed single group pretest-posttest design employing time serious design. On the other hand, the finding of these study show the effects of using inquiry-based learning excluding the local context, where the present study was conducted. However, in the study area, inquiry-based learning seems to have been a missing feature of English as a foreign language leaning in general and writing skills in particular. Thus, examining the effects of 
using inquiry-based learning on EFL students' critical thinking skills in the local context was relevant to fill the research gap.

\section{Why inquiry-based learning for EFL students' critical thinking skills?}

Critical thinking plays a significant role for higher education ESL/EFL learners' in order to produce sound written texts including argumentative essays (Klimova, 2013; Ghaemi \& Mirsaeed, 2017). However, various studies conducted on students' critical thinking skills and writing performance revealed that students are commonly challenged to support their arguments through referring to and synthesizing academic sources due to poor reasoning and unsupported claims. Especially, synthesizing sources is a complex task to second and foreign language learners to comprehend, paraphrase, and summarize written texts (Alagozlu, 2007; Goodwin, 2014). Evaluating and synthesizing sources into their own writing are the elements of critical thinking that students find challenging to express their own academic thoughts (Ahmad et al., 2014; Melles, 2009; Wette, 2010).

Fostering critical thinking skills is a challenging task nowadays since learners are exposed to an enormous information influx, such as the Internet (Klimova, 2013). They are offered pre-chewed chunks of ideas and opinions and often, they are not made to think about them. However, a critical thinker should be alerted and in his/ her inquisitive nature inquire, judge and evaluate all such sources critically. Hence, using inquirybased learning in writing classes is helpful to foster students' critical thinking skills.

Paul and Elder (2007) states that the conventional way of teaching, the product approach, is criticized in its inadequacy to prepare university graduates to deal with existing complex situations, because students are assumed to develop critical thinking skills depending on books, lecture notes, and handouts. It also led students learn with lack of interest on topics, receive rather than to think critically and search for knowledge. The students were not mostly motivated to observe their environment critically, inquire things, investigate problems, and create new knowledge (Ferris \& Hedgcock, 2013; Graham, MacArthur, \& Fitzgerald, 2013; Yen, 2014). However, in learning situations like inquiry-based learning where critical thinking is emphasized; students aim to understand ideas with range of explorations and follow new leads; learn with curiosity or interest of topics, and reach on implications.

Local researchers like Daniel (2004); Dawit and Yalew (2008) find out that conventional teaching methods are still in use though teachers are expected to use active learning methods. The lecture method, which is considered as the conventional method of teaching, is used in colleges that teachers usually focus on giving lectures, and students depend primarily on lecture where discovery is not that much encouraged. The researcher's language teaching experience also shows that students were not that much learning to improve their critical thinking skills in writing classes. In other terms, the students' papers were not adequately developed due to lack of interpretation, analysis, evaluation, inference, explanation, and self-regulation. However, there are no local studies conducted to investigate the effects of using inquiry-based writing instruction in EFL context. Therefore, the present study examines the effects of using inquirybased learning on EFL students' critical thinking skills since the method involves students in seeking, collecting, analyzing, synthesizing and evaluating information based on student interest. 


\section{Research question}

This study was designed to answer the following research question:

What are the effects of using inquiry-based learning on EFL students' critical thinking skills?

\section{Research methodology \\ Design of the Study}

The research design of the study was quasi-experimental that employs a time series design with single group participants. For the purpose of this study, the participants were given a series of three argumentative essay writing pretests before the intervention, inquiry-based argumentative writing instruction, and other three similar series of argumentative essay writing posttests.

\section{Participants}

In this study, a total of 20 EFL second year undergraduate university students who were enrolled for advanced writing skills course were selected using comprehensive sampling method. In the students' university stay, Advanced Writing Skills Course is the final writing course given to them. Before this course, the students have taken both Communicative English Skills and Basic Writing Skills, and Intermediate Writing Skills Courses in their university stay. Earlier to these university courses, they have learned English language subject beginning from grade one to university.

\section{Data gathering instruments}

The data on the students' critical thinking skills were gathered through tests, focus group discussion, and student-reflective journal.

\section{Tests}

The test that comprises both pretests and posttests was used to gather data on students' critical thinking skills. Three consecutive argumentative essay writing pre-tests were given to understand the students' existing critical thinking skills. Likewise, other three consecutive argumentative essay writing posttests were also given to determine the effects of the intervention, whether students' critical thinking skills were improved. The tests were developed by the researchers considering the students' local context and their background knowledge.

The critical thinking skills rubric was adapted from Facione (2015), "Critical Thinking: What It is and Why It Counts" (from APA Report: Expert Consensus Statement on Critical Thinking) incorporating common critical thinking skills including interpretation, analysis, evaluation, inference, and explanation. The rubric is a four point scale from one to four that refers to poor, good, very good, and excellent respectively. Two experienced EFL university teachers marked students' argumentative essays independently based on the given criteria. Training on the use of the rubric was given to the raters. Inter-rater reliability was calculated with Pearson's correlations (Pearson's, r), and it was 0.75 which shows the reliability of the test. 


\section{Focus group discussion}

The focus group discussion was needed to gather qualitative data on students' critical thinking skills empowerment. The students were asked to forward their views on the relevance of inquiry-based learning to enhance their skills to interpret, analyze, evaluate, infer, explain, and self-regulate in writing argumentative essays.

\section{Student-reflective journal}

The Student-Reflective Journal was employed to collect data on the effectiveness of inquiry-based learning on students' critical thinking skills. Accordingly, the participants were reported their feelings on the effectiveness of inquiry-based learning method and their critical thinking skills empowerment.

\section{Procedure and data collection}

In the data collection, first, a teaching material used to teach argumentative essay writing was prepared using the literature in accordance with inquiry-based learning method and critical thinking skills. In other terms, the teaching was developed in the way that enable the students to make observations; pose questions; examine sources; gather, analyze, interpret, and synthesize data; propose answers, explain and predict; communicate findings through discussion and reflection; apply their findings to the real situation, and follow up new questions that arise in the process because these are the focuses of inquiry-based learning. On the other hand, it also developed in the way that enable students to interpret, analyze, infer, evaluate, explain, and self-regulate which are the core critical thinking skills. In sum, the teaching material was prepared considering the components of inquiry-based learning, and critical thinking skills.

Then, three consecutive argumentative essay writing pre-tests were administered to the students to identify their critical thinking performance before the intervention. Following the pre-tests, the intervention was given.

The intervention was an inquiry-based argumentative essay writing instruction delivered for 4 weeks using the aforementioned teaching material. In the teaching-learning process students discover their own writing topics, generate ideas, evaluate what they have and what they need, gather and evaluate information from different sources, write up drafts with evidences, discuss with colleague and subject area experts for feedback, and write up essays related to their real life situation. When the intervention was given, the Student-Reflection Journal was collected from the students.

Next to the completion of the teaching-learning practice, the participants were given three consecutive argumentative essay writing post-tests which were identical with the pre-tests. The post-tests were needed to determine whether the inquiry-based essay writing instruction make improvements on students' critical thinking skills. By the completion of the post-tests, the focus group discussion was conducted.

\section{Data analysis methods}

The quantitative data which were gathered through pre-tests and post-tests were analyzed using One-Way Repeated Measures ANOVA, using the Statistical Package for Social Science (SPSS) version 23 software program. One-Way Repeated Measures ANOVA was used to examine whether there were differences on students' critical thinking skills 
in writing argumentative essays before and after the intervention. On the other hand, the qualitative data which were collected through focus group discussion and studentreflective journal were analyzed through narration.

\section{Result and discussion}

\section{Essay writing tests}

The students were given three essay writing pretests and other three essay writing posttests in order to measure their critical thinking skills before and after the intervention. Accordingly, this section presents the students' test results gained from the pretests and posttests which were analyzed using One Way Repeated Measures ANOVA.

Table 1 indicates that the students' Mean scores in Pretest-1, Pretest-2, and Pretest-3, were $38.15,38.00$, and 38.35 , respectively. The table also depicts that the students' Mean scores in Posttest-1, Posttest-2, and Posttest-3, were 65.90, 65.70, and 66.25, respectively. From these results, we can understand that the students' Mean scores in the pretests were similar. Likewise, their Mean scores in the Posttests were also similar. However, when the Mean scores in the Pretests and Posttests were compared, they have differences. In other words, the students' Mean scores in the posttests were greater than those of the pretests. It indicates that the intervention made the differences on the students' pretest and posttest Mean scores. In sum, it can be understood that the inquiry-based argumentative essay writing instruction has positive effects on the students' critical thinking skills.

The findings of this study imply that inquiry-based learning has improved EFL students' critical thinking skills which includes interpretation, analysis, inference, evaluation, explanation, and self-regulation. In line with this research finding, previous studies also show that inquiry-based learning has positive impacts on students' critical thinking skills. Ash and Kluger-Bell (2012) find out that by using inquiry-based learning in writing lessons, students develop critical thinking skills, and learn how to generate and organize ideas through investigation or/and discussion to find out alternative ideas, and produce sound written papers. Inquiry-based learning is appropriate when deep discipline knowledge; higher-order thinking skills or strategies including reasoning skills; adequate motivational beliefs or attitude and value are intended as learning outcomes, rather than lower-order thinking skills like, to recall facts.

Table 2 shows the Within-Subjects Effects of the tests. In the table, the Sphericity Assumed indicated that 5 with-in subjects $d f$, and 95 errors $d f$. The Mean Square is 4632.348 with $8.468 \mathrm{~F}$, and Significance value is .000 . F $(5,95)=547.065, p<0.005$. It means that the students test scores have differences based on time, but the differences in all times are not the same.

Table 1 Descriptive statistics

\begin{tabular}{llll}
\hline Tests & Mean & Std. Deviation & N \\
\hline Pretest-1 & 38.15 & 4.738 & 20 \\
Pretest-2 & 38.00 & 4.877 & 20 \\
Pretest-3 & 38.35 & 4.626 & 20 \\
Posttest-1 & 65.90 & 5.350 & 20 \\
Posttest-2 & 65.70 & 5.273 & 20 \\
Posttest-3 & 66.25 & 4.564 & 20 \\
\hline
\end{tabular}


Table 2 Tests of within-subjects effects

\begin{tabular}{lllllllc}
\hline Source & & $\begin{array}{l}\text { Type III sum } \\
\text { of squares }\end{array}$ & df & Mean square & F & Sig. & $\begin{array}{c}\text { Partial eta } \\
\text { squared }\end{array}$ \\
\hline Time & Sphericity Assumed & $23,161.742$ & 5 & 4632.348 & 547.065 & .000 & .966 \\
& Greenhouse-Geisser & $23,161.742$ & 1.205 & $19,214.011$ & 547.065 & .000 & .966 \\
& Huynh-Feldt & $23,161.742$ & 1.242 & $18,641.657$ & 547.065 & .000 & .966 \\
& Lower-bound & $23,161.742$ & 1.000 & $23,161.742$ & 547.065 & .000 & .966 \\
Error (Time) & Sphericity Assumed & 804.425 & 95 & 8.468 & & & \\
& Greenhouse-Geisser & 804.425 & 22.904 & 35.122 & & & \\
& Huynh-Feldt & 804.425 & 23.607 & 34.076 & & & \\
& Lower-bound & 804.425 & 19.000 & 42.338 & & & \\
\hline
\end{tabular}

Thus, in order to identify the difference among each of the test scores, Post Hoc analysis was run. The Post Hoc analysis for a repeated measures variable is a paired sample t-test.

Table 3 depicts that there were no difference between pretest- 1 and pretest-2 (.603); pretest- 1 and pretest-3 (.163); pretest- 2 and pretest-3 (.273). In the same manner, there were no differences between posttest-1 and posttest-2 (.464); posttest-1 and posttest-3 (.376); posttest- 2 and posttest-3 (.280). In contrast, there were differences in all of the remaining combinations (.000). It indicates that the differences were made due to the intervention given to the students. Thus, it can be concluded that the inquiry-based argumentative writing instruction improves the students' critical thinking skills.

This finding shows that using inquiry-based learning in EFL classroom fosters students' abilities to interpret, analyze, infer, evaluate, explain, and self-regulate which are the core critical thinking skills. In line with this research finding, Ghaemi and Mirsaeed (2017) revealed that doing inquiry-based activities in EFL classroom increased the critical thinking ability of the students which enable them to analyze, evaluate, and explain

Table 3 Paired samples test

\begin{tabular}{llllllll}
\hline Paired differences & & & & & \\
& & Mean & Std. Deviation & Std. Error mean & t & df & Sig. (2- tailed \\
\hline Pair 1 & Pre-test 1 - Pre-test 2 & .150 & 1.268 & .284 & .529 & 19 & .603 \\
Pair 2 & Pre-test 1 - Pre-test 3 & -.200 & .616 & .138 & -1.453 & 19 & .163 \\
Pair 3 & Pre-test 1 - Post-test 1 & -27.750 & 5.408 & 1.209 & -22.946 & 19 & .000 \\
Pair 4 & Pre-test 1 - Post-test 2 & -27.550 & 5.246 & 1.173 & -23.485 & 19 & .000 \\
Pair 5 & Pre-test 1 - Post-test 3 & -28.100 & 4.610 & 1.031 & -27.259 & 19 & .000 \\
Pair 6 & Pre-test 2 - Pre-test 3 & -.350 & 1.387 & .310 & -1.129 & 19 & .273 \\
Pair 7 & Pre-test 2 - Post-test 1 & -27.900 & 5.684 & 1.271 & -21.952 & 19 & .000 \\
Pair 8 & Pre-test 2 - Post-test 2 & -27.700 & 5.555 & 1.242 & -22.302 & 19 & .000 \\
Pair 9 & Pre-test 2 - Post-test 3 & -28.250 & 4.854 & 1.085 & -26.025 & 19 & .000 \\
Pair 10 & Pre-test 3 - Post-test 1 & -27.550 & 5.346 & 1.195 & -23.048 & 19 & .000 \\
Pair 11 & Pre-test 3 - Post-test 2 & -27.350 & 5.174 & 1.157 & -23.642 & 19 & .000 \\
Pair 12 & Pre-test 3 - Post-test 3 & -27.900 & 4.553 & 1.018 & -27.407 & 19 & .000 \\
Pair 13 & Post-test 1 - Post-test 2 & .200 & 1.196 & .268 & .748 & 19 & .464 \\
Pair 14 & Post-test 1 - Post-test 3 & -.350 & 1.725 & .386 & .495 & 19 & .376 \\
Pair 15 & Post-test 2 - Post-test 3 & -.550 & 2.212 & & 112 & .280 \\
\hline
\end{tabular}


information. Thus, it shows that using inquiry-based writing instruction enhances students' critical thinking skills.

\section{Focus group discussion}

The students' focus group discussion result revealed that the use of inquiry-based learning in argumentative essay writing classes can enhance students' critical thinking skills. Most of the focus group discussion participants reported that they had not wrote effective argumentative essays before they use inquiry-based learning method. However, after using this method of learning, they have developed their critical thinking skills including interpretation, analysis, evaluation, inference, explanation, and self-regulation. For instance, one of the participants reported that his critical thinking skills have been enhanced after learning argumentative essay writing through inquiry-based learning method because he has developed the way to interpret, analyze, and evaluate information. He can generate logical ideas which are better to persuade his audiences, and write essays without emotional feelings.

The other focus group discussion participant voiced that the learning method empowers her critical thinking skills because before using inquiry-based learning her writings were not appropriate for audience. However, after taking the lessons in the intervention, she knows what to write considering her purpose and audience, how to analyze information, and how to produce reasonable argumentative essays.

The other student also mentioned his performance as follows:

My critical thinking skills such as interpretation, analysis, evaluation, inference, explanation, and self-regulation are very good now. Especially, when I pick two points from these points, analysis and evaluation, I can analyze and evaluate written arguments because of the inquiry-based essay writing instruction. So now, I can easily interpret, analyze, and evaluate data, and even regulate myself to write my argumentative essay to persuade my audience.

In a similar manner, another participant also reported that in inquiry-based learning, she discovered her writing topic, searched for information, and evaluated, criticized and analyzed the collected data, and wrote drafts, incorporated necessary feedbacks, and produced effective essays in contrast to the previous methods. She further explained that during this process, her critical thinking skills were enhanced due to the instruction given through inquiry-based learning. Similarly, another respondent also said that after learning through inquiry-based learning, his critical thinking skills were enhanced. As he further elaborated, he could become to analyze and evaluate information in writing argumentative essays while using this method.

In addition, the students reported that the critical thinking skills that they enhanced in the teaching learning process were relevant to their real life situations. One of them stated that "every English language graduate person and critical thinking towards writing dependently go together. I am going to do two things in the future as an English graduate man. These are critically writing texts and critically evaluating what another person has written. So, I think, the critical thinking skills that I developed through inquiry-based writing instruction are helpful to the rest of my life". 
The students mentioned that critical thinking helps in their work life as university graduate students because it has a lot of things for them. According to their speech, they should be competitive enough to become successful in their work life. So, being a good critical thinker helps to think differently, and to be successful. They further voiced that skills can also help them to make good decisions in their real life situations apart from their working environment. In sum, the students' focus group discussion results indicated that the students' critical thinking skills including interpretation, analysis, evaluation, inference, explanation, and self-regulation were enhanced due to the inquiry-based writing instruction. In the same manner, Ghaemi and Mirsaeed (2017) revealed that most of the participants who used inquiry-based learning believed that their critical thinking abilities changed positively. Therefore, it is worth mentioning that there should be opportunities for students to have enough exposure to inquiry-based learning.

\section{Student-reflective journal}

The data gained from the students' reflective journal indicated that when the students used inquiry-based essay writing instruction, they have developed their critical thinking skills including interpretation, analysis, and evaluation, synthesize, inference, explanation, and self-regulation. They note that the strategies used in the teaching learning process and incorporated in the teaching material were effective to improve their critical thinking skills. The students reported that the way they learned argumentative writing has enhanced their critical thinking skills like interpretation, analysis, evaluation, inference, explanation, and self-regulation.

In line with this finding, a study conducted in Whittier College, USA to assess students' feedback on the effectiveness of inquiry-based teaching in second language pedagogy shows that the method reinforced students' understanding of the course material (Lee, 2014). In addition, McLean (2005); Abdullah (2014); Adege (2016) also revealed that empowering critical thinking skills among students in higher education especially in academic writing through the integration of critical thinking into the teaching learning process is essential in order to develop students' problem solving, decision making and communication skills which are needed for their future carrier.

Therefore, based on the findings of the study, all together, it can be understood that using inquiry-based learning in argumentative essay writing class empowers students' critical thinking skills including interpretation, analysis, evaluation, inference, explanation, and self-regulation. In other terms, when the students have used inquiry-based argumentative writing instruction, they comprehend and expressed the meaning of their writing issues and judgments in their argumentative essays. They recognized the then argumentative issues and described them in their essays. The students have collected data on their topics and constructed categories of protagonist and antagonist ideas for their argumentative essay development. They also paraphrased ideas taken from other sources in their own words. These indicate that the students have developed their interpretation skills which is one of the core critical thinking skills.

In the same vein, the students have enhanced their analysis skills through inquirybased learning. In inquiry-based writing instruction, the students identified the intended and actual inferential relationships among statements to express beliefs in their argumentative writing. The students examined ideas, detected, and analyzed 
arguments in their writing. They identified the similarities and differences between opposing ideas in developing their persuasive essays. The students drafted the relationship of sentences or/and paragraphs to each other and the main purpose of their argumentative essays. They also constructed convincing reasons to support or criticize a given argumentative idea, and reach on a strong conclusion. Thus, it shows that the students have enhanced their analysis skills which is one of the core critical thinking skills.

The results revealed that the students have developed their evaluation skills using inquiry-based instruction. In other words, in the teaching-learning process, the students have determined the credibility of their source of information while they gathered data for their writing topics. They assessed and compared the logical strengths and weaknesses of opposing arguments. They also judged whether the evidence at their hands did not contradict each other, and support their conclusion. Finally, they judged if their arguments in their argumentative essays were relevant and applicable in an existing real-life situation. It implies that the students have developed their evaluation skills, one of the core critical thinking skills through inquiry-based learning.

The students have also enhanced their inference skills in writing their argumentative essays through inquiry. This means that the students have identified pertinent thoughts needed to draw reasonable conclusions in their essays. In doing so, they formed conjectures and hypotheses; considered the relevant information, and educed consequences flowing their data. They questioned their evidence, conjectured alternatives, and drawn conclusions when they developed argumentative essays through inquiry-based learning. They constructed meaning from their readings and formulated synthesis of related ideas into a coherent perspective to produce sound argumentative essays.

Beyond interpretation, analysis, evaluation, and inference, the students explained what they think, and how they arrived at their judgments in developing their essays. In other terms, the students have developed their explanation skills due to the inquirybased writing instruction. They have presented their argumentative essays in a cogent and coherent way. They stated and justified reasons in terms of their evidential and contextual considerations upon which their results were based. They presented their reasons in the form of persuasive arguments in their essays. They also reflected on the methods, procedures, and techniques (in the classroom) they used in writing their argumentative essays.

Finally, the data gained from the student-reflective journal and focus group discussion revealed that the students have developed their self-regulation skills, which is one of the core critical thinking skills, through using inquiry-based learning. Accordingly, the students confirmed that they self-consciously monitored or corrected their judgments in analyzing and evaluating contradictory ideas in producing their argumentative essays. They questioned themselves to examine, correct, and confirm their reasons for producing essays. They double-checked their reasons by recalculating their evidence. The students reconsidered their interpretations and judgments in the view of further analysis. They revised their answers in view of the errors they discovered in their argumentative essay writing. Even, they have changed some of their concluding ideas in view of the realization that they had misjudged the importance of certain factors when coming to their earlier decisions. Altogether, using inquiry-based argumentative writing instruction enhanced EFL students' interpretation, analysis, evaluation, inference, explanation, and self-regulation skills which are the core critical thinking skills. 
In sum, though the findings of this study are in line with previous studies, most of them have examined the enhancement of critical thinking skills through using inquirybased learning in writing classes in general rather than showing the effects of the method in argumentative essay writing classes in particular. Thus, the present study exclusively revealed the effects of using inquiry-based argumentative essay writing instruction on EFL students' critical thinking skills. In other terms, it contributed to the existing literature in disclosing the effects of using inquiry-based argumentative writing instruction on EFL students' critical thinking skills. Besides, the present study can contribute to the field of English as a foreign language education by showing the effects of using inquiry-based learning on students' critical thinking skills in the local context where this study has been conducted. This is because, in the study area, inquiry-based learning seems to have been a missing feature of English as a foreign language learning.

\section{Conclusion and implication}

The findings of the study revealed that the use of inquiry-based learning in foreign language learning classroom empowers students' critical thinking skills. Inquiry-based learning has positive impacts on students' critical thinking skills which include interpretation, analysis, inference, evaluation, explanation, and self-regulation. In other terms, when the students have used inquiry-based argumentative essay writing instruction in their academic writing classes, they have comprehended and expressed their essay writing queries (interpretation); identified and examined arguments, reasons and claims (analysis); identified elements of claims, estimated alternatives, and drawn reasonable conclusions in writing their argumentative essays (inference). In the same manner, they also assessed the credibility of claims and quality of arguments made in their conclusions (evaluation); stated results, justified procedures, and presented arguments (explanation), and consciously monitored and corrected their writing activity (self-regulation) in producing argumentative essays. Thus, the students have developed their critical thinking skills by using inquiry-based argumentative writing instruction.

In inquiry-based writing instruction, the students discover writing topics; explore information on their topics; explain their discoveries, and elaborate their thinking through transforming their understanding into their real life situations. Thus, when the students came up through this distinct process in manipulating such tasks, their critical thinking skills enhance because this process develops the students' abilities to analyze, synthesize, and evaluate various thoughts. Using inquiry-based learning in argumentative writing class enhance the students' argumentative essay writing performance since the method enables them to discover their own writing topics, generate ideas, gather and evaluate information, write up drafts with evidences, discuss with colleagues and subject area experts, and produce sound argumentative essays.

When the students use inquiry-based learning in argumentative essay writing lessons, they generate and organize ideas through investigation and discussion, and later produce sound written texts. The students develop reasoning skills, collaborative working, and make connections to real life experiences when they learn through inquiry-based learning. The critical thinking skills that the EFL students develop through the inquiry-based writing instruction are relevant to their future working environment to write convincing texts and critically evaluate what other individuals have written. The abilities to interpret, 
analyze, evaluate, infer, explain, and self-regulate help the university students to be lifelong learners, and to be competitive enough in their future working life.

Therefore, inquiry-based writing instruction is suggested as a means to improve EFL students' critical thinking skills because the method incorporates activity oriented learning, logical arguments, and collaboration. This is to imply the need to promote inquirybased learning which is based on a discovery approach that mostly involve students in seeking, collecting, analyzing, synthesizing and evaluating information based on students' interest. It is because using inquiry-based learning in writing classes promotes students' academic performance and makes students active, problem solver, autonomous, and lifelong learners. Accordingly, EFL teachers should use inquiry-based learning in their language classrooms in order to develop students' critical thinking skills. Similarly, teaching material developers need to consider the inquiry-based learning principles in developing language teaching materials so that students' improve their critical thinking skills. Students should also use the inquiry-based learning techniques to produce effective argumentative texts, to be critical thinkers, and become lifelong learners.

Finally, the number of participants and the time given to the intervention were relatively small. However, it does not mean that the findings of the study are not representative since the selected participants have similarities with other students. In addition, it does not mean that the intervention is completely inadequate since the students practiced the whole inquiry process repeatedly. It is to mean that the findings of the study would have been more representatives and convincing if a greater number of participants had been included, and more time to the intervention had been used in the study. As a result, such future exploration would have contributed to the current study and is certainly an area ripe for future research. Furthermore, future studies should be also conducted on the effects of using inquiry-based learning on students' speaking, reading, and listening skills to widen the use of inquiry-based learning in EFL instruction.

Abbreviations

EFL: English as a Foreign Language; ANOVA: Analysis of Variance; SPSS: Statistical Package for Social Sciences

Acknowledgements

Not Applicable.

Authors' contributions

Both authors of the research had their own contributions in the process of conception and design, acquisition of data, and analysis and interpretation of data. Both have been involved in revising the manuscript critically. Both take public responsibility for the whole content. Both are equally accountable for all aspects of the work. Both authors read and approved the final manuscript.

Funding

The study did not receive any funding

Availability of data and materials

Please contact corresponding author for data requests.

Competing interests

The authors declare that they have no competing interests.

Author details

${ }^{1}$ Department of English Language and Literature, Faculty of Social Sciences and Humanities, Woldia University, Woldia, Ethiopia. ${ }^{2}$ Department of English Language and Literature, Faculty of Humanities, Bahir Dar University, Bahir Dar, Ethiopia. 
Received: 30 January 2020 Accepted: 24 June 2020

Published online: 30 June 2020

\section{References}

Abdullah, T. (2014). Developing critical thinking skills through writing in an internet-based environment. International Journal of Humanities and Social Science, 4(1), 169-78.

Adege, A. (2016). The effects of explicit instruction in critical thinking on student achievement in writing academic papers, general critical thinking ability, and critical thinking dispositions. [doctoral dissertation]. Addis Ababa University.

Ahmad, J. S., Sitti, H. R., Abdul, R. H., Mohammad, N. A. G., \& Sanitah, M. Y. (2014). Levels of inquiry-based learning on writing skill in English language among high school students: A study in Makassar Indonesia. Journal of Language and Literature., $5(2), 62-66$

Alagozlu, N. (2007). Critical thinking and voice in EFL writing. Asian EFL Journal Quarterly, 9(3), 118-136.

Ash, Doris \& Kluger-Bell, Barry (2012). Identifying inquiry in the k-5 classroom. Retrieved from http://www.nsf.gov/pubs/2000/ nsf99148/ch_10.html.

Buranapatana, M. (2006). Enhancing critical thinking of undergraduate Thai students through dialogic inquiry. Doctoral dissertation. Australia: Canberra University.

Byker, C., Harden, G., Heafner, B., \& Holzberg. (2017). Hoping to teach someday? Inquire within: examining inquiry-based learning with first-semester undergrads. Journal of Inquiry \& Action in Education., 8(2), 54-80.

Daniel, D. (2004). Observations and reflections of the higher education teachers on the quality of teaching and learning in higher education in Ethiopia. The Ethiopian Journal of Education., 1(1), 63-81.

Dawit, M. \& Yalew, E. (2008). The role of teachers in the teaching learning process and the development of education: past, present, and future. A paper presented in an educational seminar held in August 2008. (Amharic version).

Escalante, P.A. (2013). Inquiry-Based Learning in an English as a Foreign Language Class: A Proposal. Journal of Modern Language, 19: 479-485.

Facione, P., \& Facione, N. (1994). Holistic critical thinking scoring rubric. Santa Clara: Santa Clara University.

Facione, P. A. (2011). Critical thinking: what it is and why it counts. Millbrae, CA: Measured Reasons and The California Academic Press.

Facione, P.A. (2015). Critical thinking: what it is and why it counts, from APA report: Expert consensus statement on critical thinking.

Ferris, D., \& Hedgcock, J. (2013). Teaching L2 composition: purpose, process, and practice. Mahwah, NJ, New York, NY: Routledge: McGraw-Hill.

Ghaemi, F., \& Mirsaeed, S. (2017). The impact of inquiry-based learning approach on critical thinking skill of EFL students. EFL Journal, 2(2), 89-102.

Goodwin, B. (2014). Teach critical thinking to teach writing. Educational Leadership, 71(7), 78-80.

Graham, S., MacArthur, C. A., \& Fitzgerald, J. (2013). Best practices in writing instruction. New York: Guilford Press.

Hilsdon, J. (2010). Critical thinking. Learning development with Plymouth University. Retrieved from: http://www.plymouth.ac. uk/learn

lakovos, T. (2011). Critical and creative thinking in the English language classroom. International Journal of Humanities and Social Science, 1(8), 82-86

Ismail, N., Alias, S., \& Albakri, I. (2006). Inquiry-Based Learning: A New Approach to Classroom Learning. English Language Journal, 2(1)13-24.

Klimova, B. F. (2013). Developing thinking skills in the course of academic writing. Procedia - Social and Behavioral Sciences, 93, 508-511.

Lee, Y. H. (2014). Inquiry-based teaching in second and foreign language pedagogy. Journal of Language Teaching and Research, 5(6), 1236-1244 Academy Publisher Manufactured in Finland.

Lessner, S., \& Craig, C. (2010). Invention as inquiry-based learning in first year writing. Writing Spaces: Readings on Writing, 1(1), $126-45$.

McLean, C. (2005). Evaluating critical thinking skills: two conceptualizations. The Journal of Distance Education., 20(2), 1-20.

Melles, G. (2009). Teaching and evaluation of critical appraisal skills to postgraduate ESL engineering students. Innovations in Education and Teaching International, 46(2), 161-170.

Naryanti (2017). Improving students' english writing skill through inquiry-based learning mthod. (Master's Thesis). State Institute for Islamic Studies.

Paul \& Elder (2007). A guide for educators to critical thinking competency standards: standards, principles, performance indicators, and outcomes with a critical thinking master rubric. The Foundation for Critical Thinking. http://www. criticalthinking.org/.

Qing, L., \& Jin, S. (2007). An analysis of language teaching approaches and methods: effectiveness and weakness. US-China Education Review., 4(1), 69-71.

Rejeki, S. (2017). Inquiry-based language learning (IBLL): theoretical and practical views in English classroom. English Franca., $1(2), 135-148$

Richards, J. C., \& Rodgers, T. S. (2001). Approaches and methods in language teaching. Cambridge: Cambridge University Press.

Wette, R. (2010). Evaluating student learning in a university-level EAP unit on writing using sources. Journal of Second Language Writing, 19(3), 158-177.

Yen, P.H. (2014). The Impact of PPP and TBLT on Vietnamese Students' Writing Performance and Self-Regulation. [Doctoral thesis]. KU Leuven University.

\section{Publisher's Note}

Springer Nature remains neutral with regard to jurisdictional claims in published maps and institutional affiliations. 